http://dx.doi.org/10.11646/zootaxa.3941.4.5

http://zoobank.org/urn:lsid:zoobank.org:pub:365839DF-9FF8-46F6-A977-91F59B51DE85

\title{
New material of Longipteryx (Aves: Enantiornithes) from the Lower Cretaceous Yixian Formation of China with the first recognized avian tooth crenulations
}

\author{
XURI WANG ${ }^{1}$, BO ZHAO $^{2,3}$, CAIZHI SHEN ${ }^{2}$, SIZHAO LIU ${ }^{2}$, CHUNLING GAO ${ }^{2}$, \\ XIAODONG CHENG $^{2} \&$ FENGJIAO ZHANG ${ }^{2}$ \\ ${ }^{1}$ Institute of Geology, Chinese Academy of Geological Sciences; Key Laboratory of Paleontology and Stratigraphy, Ministry of Land \\ and Resources, No. 26 Baiwanzhuang Road, Xicheng District, Beijing, PR China \\ ${ }^{2}$ Dalian Natural History Museum, No. 40 Xicun Street Heishijiao Shahekou District, Dalian City, Liaoning Province, PR China \\ ${ }^{3}$ Corresponding author.E-mail: zhaobo1961@163.com; wang198109@163.com
}

\begin{abstract}
We report on a new specimen of Longipteryx chaoyangensis from the Lower Cretaceous Yixian Formation in Chaoyang, Liaoning Province, China. The new material preserves previously unknown tooth crenulations. This is the first recognized tooth crenulations within Aves. It not only provides new information regarding the anatomy of the Longipteryx, but also sheds new light on the trophic specialization of this genus and even this family. It was discovered from the Yixian Formation, which is older than the Longipteryx chaoyangensis bearing-Jiufotang Formation. This new discovery also expands the known stratigraphic range of Longipteryx.
\end{abstract}

Key words: Enantiornithes, Lower Cretaceous, Yixian Formation, tooth morphology

\section{Introduction}

During the last two decades, over 60 avian species have been reported from the Lower Cretaceous Jehol Group of northeastern China (Chiappe \& Walker 2002; Zhou \& Zhang 2006; O'Connor et al. 2013; Wang et al. 2014). Most of them are preserved nearly completely, and some are even preserved with gastroliths and plumages, which provide direct evidence for understanding their morphology, evolution and lifestyles (Zhou \& Zhang 2002; Zhou et al. 2004; Hou et al. 2004; Chiappe et al. 2008, 2014; O’Connor \& Chiappe 2011; O' Connor et al. 2009, 2010, 2011, 2012, 2013). However, to date no published specimens preserve teeth with structures like serrations or crenulations. In fact, although many Mesozoic birds are toothed, and display a variety of teeth sizes and morphologies (Zhou \& Zhang 2001, 2002; Zhou et al. 2008; Wang et al. 2010), only Sulcavis geeorum O'Connor et al., 2013 has been reported with tooth enamel specialization. Here we report on a new fossil bird (DNHMD2889) from the Lower Cretaceous Yixian Formation in Chaoyang, western Liaoning, China with the first recognized tooth crenulations. DNHM-D2889 shows close similarities with Longipteryx chaoyangensis Zhang et al., 2001, thus providing new information regarding the anatomy and trophic specialization of Longipteryx.

Institutional abbreviations. IVPP, Institute of Vertebrate Paleontology and Paleoanthropology, Chinese Academy of Sciences, Beijing, China; DNHM, Dalian Natural History Museum, Dalian City, Liaoning Province, China.

\section{Systematic Paleontology}

Aves Linnaeus, 1758

Pygostylia Chiappe, 2002 
TABLE 3. Comparisons of important bone lengths between DNHM-D2889 and Longipteryx chaoyangensis (IVPPV12325).

\begin{tabular}{lllll}
\hline Specimen & intermembral index & femur/tibiotarsus & femur/ humerus & clavicle/hypocleideum \\
\hline DNHM-D2889 & 1.2 & 0.8 & 0.8 & 1.1 \\
L. chaoyangensis & 1.5 & 1.0 & 0.6 & 1.8 \\
\hline
\end{tabular}

To date, the only way to infer the trophic habit of enantiornithines from the Jehol Group is through their cranial or dental morphology (O'Connor et al. 2013). Longipterygids constitute a distinct clade within enantiornithines because they have a unique long rostrum, dentition restricted to the premaxilla and rostral-most portion of the dentary, and relatively long forelimbs. They are interpreted as having fed on fish, worms or bivalves (Zhang et al. 2001; Hou et al. 2004; Morschhauser et al. 2009; O'Connor et al. 2009; Li et al. 2013). DNHM-D2889 preserves crenulations on the caudal margins of its premaxillary teeth and probably on the dentary teeth. This form of tooth ornamentation has neither been observed among birds, nor among non-avian dinosaurs. We consider the crenulations as true structures because they are only present on the caudal margins of these teeth. If they were formed by glue or sediments, they would probably also present on the anterior margins of premaxillary teeth. They are not an artefact of preparation because they are prominently arranged in two lines along the caudal margin, and their surfaces are smooth, which may be interpreted as worn facets. Moreover, very faint crenulations also can be observed in the holotype of L. chaoyangensis, on the caudal margins of premaxillary teeth (IVPP-V12325). These tooth crenulations are not the first ornament found on teeth within Aves, since longitudinal grooves on the lingual surface of premaxillary teeth have been observed in Sulcavis geeorum O'Connor et al., 2013 (O'Connor et al. 2013). The diversity of dental shapes may reflect differences in food items between taxa (O'Connor et al. 2013). The large, recurved, and labiolingually compressed teeth with crenulations and recurved sharp manual and pedal claws suggest that Longipteryx chaoyangensis probably occupied more extensive trophic niches than previously thought. They could probably prey on not only fish but also some small terrestrial vertebrates. This feeding habit further expanded their food chain and their living space. This unique dental specialization not only expands the diversity of dental morphologies among Mesozoic birds, but also explained why longipterygids were the most diversified enantiornithines.

\section{Acknowledgments}

We are grateful to Guo Yanfang and Stephanie Abramowicz for the preparation and photographing of the specimen, respectively. Thanks also go to Luis M. Chiappe for reviewing and approving the manuscript, to Jingmai K. O'Connor and You Hailu for constructive communications, and to Ji Shu'an for providing the microscope. We are also grateful to the three anonymous reviewers for their brilliant comments and to Trevor Worthy for his editorial handling with this manuscript. We would like to thank Zhang Fucheng for accessing the specimens deposited at IVPP. This research was supported by the Ministry of Science and technology of China (Project 973: 2012CB822004), China Geological Survey (Project number: 1212011120105) and Chinese Academy of Geological Sciences (Project number: JB1206).

\section{References}

Chiappe, L.M. (1995) The phylogenetic position of the Cretaceous birds of Argentina: Enantiornithes and Patagopteryx deferrariisi. Courier Forschungsinstitut Senckenberg, 181, 55-63.

Chiappe, L.M. (2002) Basal bird phylogeny: problems and solutions. In: Chiappe, L.M. \& Witmer, L.M. Mesozoic Birds: Above the Heads of Dinosaurs. Berkeley: University of California Press, pp. 72-448.

Chiappe, L.M., Zhao, B., O'Connor, J.K., Gao, C., Wang, X., Habib, M., Marugan-Lobon, Meng, Q. \& Cheng, X. (2014) A new specimen of the Early Cretaceous bird Hongshanornis longicresta: insights into the aerodynamics and diet of a basal ornithuromorph. PeerJ, 2, e234. http://dx.doi.org/10.7717/peerj.234

Chiappe, L.M., Marugan-Lobon, J., Ji, S. \& Zhou, Z. (2008) Life history of a basal bird: morphometrics of the Early Cretaceous Confuciusornis. Biology letters, 4, 719-723. 
http://dx.doi.org/10.1098/rsbl.2008.0409

Chiappe, L.M., Suzuki, S., Dyke, G.J., Watabe, M., Tsogtbaatar, K. \& Barsbold, R. (2007) A new enantiornithine bird from the Late Cretaceous of the Gobi Desert. Journal of Systematic Palaeontology, 5, 193-208.

http://dx.doi.org/10.1017/S1477201906001969

Chiappe, L.M. \& Walker, C.A. (2002) Skeletal morphology and systematics of the Cretaceous Euenantiornithes (Ornithothoraces: Enantiornithes), In: Chiappe, L. M. \& Witmer, L. M. Mesozoic birds: above the heads of dinosaurs. Berkeley: University of California Press, pp. 240-267.

Currie, P.J., Rigby, J.K. \& Sloan, R.E. (1990) Theropod teeth from the Judith River Formation of southern Alberta, Canada, In: Carpenter, K. \& Currie, P. J. Dinosaur Systematics: Perspectives and Approaches. Cambridge: Cambridge University Press, pp. 107-125.

Hou, L., Chiappe, L.M., Zhang, F. \& Chuong, C.M. (2004) New Early Cretaceous fossil from China documents a novel trophic specialization for Mesozoic birds. Naturwissenschaften, 91, 22-25. http://dx.doi.org/10.1007/s00114-003-0489-1

Li, L., Gong, E., Zhang, L., Yang, Y. \& Hou, L. (2010) A new Enantiornithine bird (Aves) from the Early Cretaceous of Liaoning, China. Acta Palaeontologica Sinica, 49, 524-531.

Li, L., Wang, J., Xi, Z. \& Hou, S. (2012) A New Enantiornithine bird from the Lower Cretaceous Jiufotang Formation in Jinzhou Area, Western Liaoning Province, China. Acta Geologica Sinica (English Edition), 86, 1039-1044. http://dx.doi.org/10.1111/j.1755-6724.2012.00729.x

Linnaeus, C. (1758) Systems Naturae. Salvii Laurentii Holmiae, 10th edition, 824.

Liu, Y., Ji, Q., Ji, S., You, H., Lü, J., Kuang, H., Jiang, X., Peng, N., Xu, H., Yuan, C. \& Wang, X. (2010) Late Mexozoic Terrestrial stratigraphy, biotas and geochronology in North-east China. Acta Geoscientica Sinica (English Edition), 31, $42-45$.

Morschhauser, E.M., Varricchio, D.J., Gao, C., liu, J, Wang, X., Cheng, X. \& Meng, Q. (2009) Anatomy of the Early Cretaceous bird Rapaxavis pani, a new species from Liaoning Province, China. Journal of Vertebrate Paleontology, 29, $545-554$. http://dx.doi.org/10.1671/039.029.0210

O' Connor, J.K., Wang, X., Chiappe, L.M., Gao, C., Meng, Q., Cheng, X. \& Liu, J. (2009) Phylogenetic support for a specialized clade of Cretaceous enantiornithine birds with information from a new species. Journal of Vertebrate Paleontology, 29, 188-204.

http://dx.doi.org/10.1080/02724634.2009.10010371

O Connor, J.K., Zhou, Z. \& Zhang, F. (2010) A reappraisal of Boluochia zhengi (Aves: Enantiornithes) and a discussion of intraclade diversity in the Jehol avifauna, China. Journal of Systematic Palaeontology, 9, 51-63.

O’Connor, J.K., Chiappe, L.M., Gao, C. \& Zhao, B. (2011) Anatomy of the Early Cretaceous enantiornithine bird Rapaxavis pani. Acta Palaeontologica Polonica, 56, 463-475. http://dx.doi.org/10.4202/app.2010.0047

O'Connor, J.K., Sun, C., Xu, X., Wang, X. \& Zhou, Z. (2012) A new species of Jeholornis with complete caudal integument. Historical Biology, 24, 29-41. http://dx.doi.org/10.1080/08912963.2011.552720

O'Connor, J.K., Zhang, Y., Chiappe, L.M., Meng, Q., Quanguo, L. \& Di, L. (2013) A new enantiornithine from the Yixian Formation with the first recognized avian enamel specialization. Journal of Vertebrate Paleontology, 33, 1-12.

Rauhut, O.W. \& Werner, C. (1995) First record of the family Dromaeosauridae (Dinosauria: Theropoda) in the Cretaceous of Gondwana (Wadi Milk Formation, northern Sudan). Palaontologische Zeitschrift, 69, 475-489. http://dx.doi.org/10.1007/BF02987808

Sankey, J.T., Brinkman, D.B., Guenther, M. \& Currie, P.J. (2002) Small theropod and bird teeth from the Late Cretaceous (late Campanian) Judith River Group, Alberta. Journal of Paleontology, 76, 751-763. http://dx.doi.org/10.1666/0022-3360(2002)076\%3C0751:STABTF\%3E2.0.CO;2

Swisher, C.C., Wang, X., Zhou, Z., Wang, Y., Jin, F., Zhang, J., Xu, X. \& Zhang, F. (2002) Further support for a Cretaceous age for the feathered-dinosaur beds of Liaoning, China: New ${ }^{40} \mathrm{Ar} /{ }^{39}$ Ar dating of the Yixian and Tuchengzi Formations. Chinese Science Bulletin, 47, 136-139.

Walker, C.A. (1981) New subclass of birds from the Cretaceous of South America. Nature, 292, 51-53. http://dx.doi.org/10.1038/292051a0

Wang, M., O'Connor, J.K. \& Zhou, Z. (2014) A new robust enantiornithine bird from the Lower Cretaceous of China with scansorial adaptations. Journal of Vertebrate Paleontology, 34, 657-671. http://dx.doi.org/10.1080/02724634.2013.812101

Wang, X., O'Connor, J.K., Zhao, B., Chiappe, L.M., Gao, C. \& Cheng, X. (2010) New species of Enantiornithes (Aves: Ornithothoraces) from the Qiaotou Formation in Northern Hebei, China. Acta Geologica Sinica (English Edition), 84, 247-256. http://dx.doi.org/10.1111/j.1755-6724.2010.00156.x

Zhang, F., Zhou, Z., Hou, L. \& Gu, G. (2001) Early diversification of birds: evidence from a new opposite bird. Chinese Science Bulletin, 46, 945-949.

http://dx.doi.org/10.1007/BF02900473 
Zhou, Z. (1995) Discovery of a new Enantiornithine bird from the Early Cretaceous of Liaoning, China. Vertebrata Palasiatica, 33, 99-113.

Zhou, Z., Clarke, J., Zhang, F. \& Wings, O. (2004) Gastroliths in Yanornis: an indication of the earliest radical diet-switching and gizzard plasticity in the lineage leading to living birds? Naturwissenschaften, 91, 571-574. http://dx.doi.org/10.1007/s00114-004-0567-z

Zhou, Z., Clarke, J. \& Zhang, F. (2008) Insight into diversity, body size and morphological evolution from the largest Early Cretaceous enantiornithine bird. Journal of Anatomy, 212, 565-577. http://dx.doi.org/10.1111/j.1469-7580.2008.00880.x

Zhou, Z. \& Zhang, F. (2001) Two new ornithurine birds from the Early Cretaceous of western Liaoning, China. Chinese Science Bulletin, 46, 1258-1264. http://dx.doi.org/10.1007/BF03184320

Zhou, Z. \& Zhang, F. (2002) A long-tailed, seed-eating bird from the Early Cretaceous of China. Nature, 418, 405-409. http://dx.doi.org/10.1038/nature00930

Zhou, Z. \& Zhang, F. (2006) A beaked basal ornithurine bird (Aves, Ornithurae) from the Lower Cretaceous of China. Zoologica Scripta, 35, 363-373. http://dx.doi.org/10.1111/j.1463-6409.2006.00234.x

Zhou, Z. \& Zhang, F. (2006) Mesozoic birds of China—a synoptic review. Vertebrata PalAsiatica, 44, 74-98. 